\title{
AS ÁGUAS TURVAS, UMA NARRATIVA SOMBRIA \\ E AS IMAGENS DO PECADO: \\ O PÂNTANO DO JOGO MAGIC: THE GATHERING
}

\author{
Heloisa Juncklaus Preis Moraes* \\ Lucas Pereira Damázio** \\ Reginaldo Osnildo ${ }^{* * *}$
}

RESUMO: O presente artigo aproxima os estudos da Teoria do Imaginário e o Magic: The Gathering, jogo de estratégia que envolve a participação de dois ou mais jogadores. Para isso, será feita uma relação simbólica entre os encantamentos, as magias, as criaturas míticas que alimentam o jogo e os conceitos do imaginário, a partir de Bachelard (2013) e de Jung (2000). O recorte analisado figura em determinada energia imaginária detentora do poder que controla a força dos pântanos, a mana preta. A análise aponta como o imaginário das águas escuras é configurado, evocado e materializado na construção da narrativa e da atmosfera que dá vida ao jogo, identificando, pela Hermenêutica Simbólica, os sete pecados capitais como evocadores de sentido.

PALAVRAS-CHAVE: Imagem; Jogo; Pântano; Água turva; Pecados.

\footnotetext{
* Doutora em Comunicação Social pela Pontifícia Universidade Católica do Rio Grande do Sul. Professora Titular do Programa de Pós-Graduação em Ciências da Linguagem da Universidade do Sul de Santa Catarina (Unisul). Líder do Grupo de Pesquisas do Imaginário e Cotidiano (pesquisa.unisul.br/imaginario).

** Mestre e Doutorando do Programa de Pós-Graduação em Ciências da Linguagem da Universidade do Sul de Santa Catarina (Unisul). Membro do Grupo de Pesquisas do Imaginário e Cotidiano.

*** Mestre em Ciências da Linguagem pelo Programa de Pós-Graduação em Ciências da Linguagem da Universidade do Sul de Santa Catarina (Unisul). Membro do Grupo de Pesquisas do Imaginário e Cotidiano.
} 


\section{Introdução}

Magic: The Gathering ${ }^{1}$ é um jogo de cartas criado por Richard Garfield, em 2003. Por meio de estratégias e imaginação, o jogo envolve a participação de dois ou mais jogadores: os players. Cada oponente evoca criaturas míticas, magias, encantamentos, artefatos, feitiços e elementos especiais para derrotar o adversário. No imaginário construído para o jogo, os jogadores fazem parte da elite dos planeswalkers, magos com poderes de invocar e comandar exércitos de seres mágicos para dominar o Multiuniverso (os diversos universos mágicos dentro do game), conforme explica o site oficial ${ }^{2}$ do jogo. Para que o player evoque criaturas e outros elementos fundamentais do jogo, há uma regra básica: é necessário utilizar a energia que permite a existência de todas as mágicas e todos os seres do Multiuniverso, a mana. $\mathrm{O}$ manual ${ }^{3}$ que acompanha as cartas informa que há cinco tipos de mana: a azul, a branca, a vermelha, a preta e a verde. De modo que a branca é a cor da lei, da ordem e da estrutura, é o elemento que representa a terra e as planícies, espaço onde habitam e transitam os homens, os anjos e os clérigos. A verde simboliza o crescimento, a vida e a força bruta que emergem das florestas e da natureza. A vermelha carrega a força e a explosão dos vulcões e do fogo, um tipo de energia poderosa e impulsiva vinda das chamas e das montanhas. A azul se utiliza da energia e do espírito das ilhas e das águas para manipular e trapacear os adversários. E, por último, há a mana preta, que representa a morte, o medo e o terror, um poder que vem dos pântanos e do medo alheio. Mana que é o objeto deste estudo.

\footnotetext{
1 A Wi ₹ardsofthe Coast LLC, bem como seus afiliados, detém integralmente os direitos, o título e a participação do jogo de cartas Magic: thegathering. Isso inclui direitos autorais, marcas, segredos comerciais, nomes comerciais, direitos de propriedade, patentes, títulos, códigos de computador, efeitos audiovisuais e imagens, temas, personagens, histórias, diálogos, cenários, ilustrações, efeitos sonoros, obras musicais e os direitos morais. Ciente que o jogo é uma propriedade intelectual, este estudo consiste em apenas analisar e compreender melhor o funcionamento do Multiuniverso, e não em comercializar as cartas ou qualquer patrimônio da empresa Wiąardsofthe Coast LLC.
}

2 Acesso em: 26 mar. de 2017: http://magic.wizards.com/

${ }^{3}$ Disponível em 26 mar. de 2017: goo.gl/zPLQP2 
Cabe ressaltar que esta pesquisa compreende o imaginário como um repositório dinâmico onde constelam e habitam as imagens, ou ainda, conforme assegura Durand (2001, p. 18), é “[...] o conjunto das imagens e relações de imagens que constitui o capital pensado do homo sapiens". A imaginação, por outro lado, está ligada ao processamento simbólico, um impulso, um movimento, uma operação das imagens, que são assimiladas e inseridas no imaginário (FERREIRA-SANTOS e ALMEIDA, 2012). Portanto, para salientar a diferença, o imaginário é, então, segundo Ferreira-Santos e Almeida (2012), “um museu" de todas as criações do pensamento humano, e abrange tanto as criações artísticas quanto biológicas, históricas e matemáticas, e a imaginação é o impulso das imagens, o processo constitutivo delas, uma ação que provê um movimento dos símbolos que, futuramente, são "acomodados” no imaginário.

Nesta perspectiva, os players, Bachelard (2013) e Jung (2000), foram convidados ao Multiuniverso do jogo Magic para auxiliar na investigação de como a matéria pântano é simbolizada e configurada, por intermédio da mana preta. Através do conceito de inconsciente coletivo junguiano e dos estudos bachelardianos, pretende-se estabelecer como a energia, cujo poder e misticismo é controlado pela força dos pântanos, aproxima-se do imaginário das águas turvas na materialização narrativa de criação das cartas.

Assim, entendendo o jogo como um texto cultural que evoca a construção de narrativas entre jogadores para a disputa, faremos a análise pautada na hermenêutica simbólica, buscando a interpretação das imagens da mana preta. A discussão se dará a partir da simbologia do elemento água (turva) e dos arquétipos, relacionando-os aos sete pecados capitais representados nas cartas e que evocam sentidos na narrativa.

\section{Arquétipos, insconsciente coletivo e imaginação material do elemento água}

Dentre os filósofos interessados em investigar profundamente as questões ligadas ao imaginário está Bachelard. Na obra $A$ água e os sonhos: ensaio sobre a imaginação material, o autor (2013) realiza uma distinção essencial para compreensão dos seus estudos ao delinear imaginação formal e imaginação material. Bachelard (2013) afirma que a imaginação formal 
dá sentido e cores às formas, sugere exuberância, volume, ângulo, parâmetro e textura às imagens. Trata-se, portanto, da imaginação que opera as figuras e concebe, principalmente, as imagens das formas e dos devaneios racionalistas. De acordo com Ferreira-Santos e Almeida (2012), a imaginação formal consiste em ser um operador que trabalha com as formas, operador cuja função é configurar e formar, sobretudo, imagens geométricas no imaginário. Para os autores (2012, p. 24), a imaginação formal brinca com as formas, "é a imaginação mais abstrata que forma e transforma as figuras, configura e transfigura conjuntos inesperados. A imaginação formal é aquela que se distrai com a geometria fácil das superfícies". Em contrapartida, a imaginação material é aquela que vai além das imagens geométricas ao estabelecer uma relação de corporeidade com os elementos líquidos, aéreos, ígneos e ctônicos, conforme aponta Bachelard (2013). No entendimento do autor (2013), é na aproximação do homem com a matéria, com o casamento entre os quatro elementos e o toque do ser imaginante, que a imaginação material se torna a raiz da força imaginante e conduz a concepção e a produção de imagens, devaneios, sonhos, que são "armazenados" e "arquivados" no imaginário.

Ao corroborar com a dedicação bachelardiana em estudar poesia e imaginação material, a chamada fase noturna do autor, Pitta (1995) afirma que a organização do mundo - ou seja, as relações existentes entre os homens e a terra, entre os homens e o universo não é o resultado de uma série de raciocínios lógicos, mas uma criação da psique humana que leva em conta afeições, sentimentos e emoções. Dentro desta percepção da autora (1995), o ser humano tem uma relação íntima com o mundo sensível: o mundo toca-o, cativa-o e transforma-o. Transformações envoltas em relações onde o homem é atraído ao psiquismo da matéria, principalmente pelos quatro elementos (terra, ar, água e fogo), aqueles que são considerados por Bacherlard (2013) como os "hormônios da imaginação". Bachelard (2013) compreende que a imaginação material é anterior à imaginação formal e a própria ação de imaginar a forma, o objeto, o espetáculo racional é um processo antecessor à imaginação material. Para o filósofo (2013, p. 3), “o pensamento erudito está ligado a um 
deveio material, a sabedoria tranquila e permanente se enraíza numa constância substância”. De modo que na visão do autor (2013), os chamados quatro elementos - terra, água, fogo e ar - constituem a base do imaginário e formam a raiz da ação imaginante. Em contrapartida, Dagognet (1980) alerta que, embora os conceitos bachelardianos tenham se empenhado em explicar a relação entre os elementos da natureza e o ser humano, os conhecimentos apresentados pelo filósofo não privilegiaram o estudo da imagem (Bachelard foi um estudioso da gênese poética). Para Dagognet (1980), o campo artístico que permite adentrar na imaginação e desbravar a potência simbólica dos quatro elementos é a poesia. Por intermédio da arte poética, ao pôr em destaque o legado da matéria sobre os estudos da forma, revela-se a materialização do imaginário e, por isso, ganhara a preferência do filósofo.

Mesmo ciente da opção metodológica de Bachelard, esta proposta insiste em aproximar imaginação material e imagem. Por isso, foi preciso recorrer aos estudos de Jung (2000), autor que propagou o conceito de inconsciente coletivo, ou universal - a existência de informações idênticas em todos os seres humanos, constituindo, portanto, um substrato psíquico comum de natureza suprapessoal que existe em cada pessoa. Tais informações idênticas, existentes no inconsciente coletivo, foram chamadas por Jung (2000, p. 16) de arquétipos: “[...] no concernente aos conteúdos do inconsciente coletivo, estamos tratando de tipos arcaicos - ou melhor - primordiais, isto é, de imagens universais que existiram desde os tempos mais remotos". De acordo com o autor (2000), os arquétipos podem ser definidos como estruturas psíquicas que servem de base para toda e qualquer produção humana. E, por serem imagens desencadeadoras, viabilizam a elaboração de material psíquico e são determinantes nas criações simbólicas, pois se tornam estruturas que orientam e amparam a conduta do indivíduo. A partir dos estudos junguianos, Pitta (1995) conceitua o arquétipo como uma imagem primordial de caráter coletivo e inato, um estado preliminar, uma zona matricial da ideia que constitui o ponto de junção entre o imaginário e os processos racionais. Para a autora (1995), arquétipos são compreendidos pelos psicanalistas como uma forma dinâmica, uma estrutura organizadora de imagens, mas que está sempre 
além das concretudes individuais, biográficas, regionais e sociais, uma vez que possui caráter universal.

O conceito de inconsciente coletivo assume uma função fundamental para este estudo, pois entende-se que, mobilizados pela ação da imaginação material - que na concepção bachelardiana são as forças propulsoras do imaginário -, os arquétipos apresentam imagens primordiais de como o ser humano identifica, compreende e representa os elementos água, terra, fogo e ar. De modo que, cada um dos elementos contém uma, ou mais, matrizes arquetípicas que catalisam as imagens ilustradas através de produções simbólicas, como a poesia, a música, a arte, o filme e os jogos. Imagens que retratam uma forma coletiva de compreensão e de relação entre o homem e as substâncias da natureza. Nessa direção, é possível identificar que os arquétipos, por meio da ação da imaginação material, desencadeiam as imagens que são produzidas na relação entre o ser humano e os elementos líquidos, aéreos, ígneos e ctônicos. De acordo com as experiências do indivíduo com esses elementos, os arquétipos podem ser apropriados e gerar diferentes formas de interpretação, de identificação e de produção simbólica. Dentre os arquétipos propostos por Carl Gustav Jung, Ulson (1988) menciona o Matriarcal (mãe), o Patriarcal (pai), o da Alteridade (anima e animus), o da Totalidade (self), o da Identidade (persona), o do Reprimido (sombra) e o da Consciência (ego). A partir desses arquétipos, Jung (2000) propôs a psicologia profunda e o seu próprio método analítico. Para a análise proposta, os arquétipos junguianos e o conceito bachelardiano de imaginação material serão os alicerces.

\section{Análise da mana preta na materialização das imagens das cartas do jogo}

Em inúmeros contos, mitologias, fábulas e poesias, as águas claras, por meio da ação da imaginação material, produzem no imaginário coletivo um simbolismo de pureza. Bachelard (2013) reconhece que uma das principais expressões poéticas das águas claras está no poder de renovação que ela emana, um símbolo natural de cura, de renovação, de purificação. Para o teórico (2013, p. 153), “com sua substância fresca e jovem, a água nos 
ajuda a nos sentir enérgicos"4. Bachelard (2013, p. 147) afirma que a água, quando sonhada em sua forma cristalina e pura, ganha sentido de "uma substância do bem", uma força renovadora e promotora de alegria. A água pura, desse modo, representa as gotas que irradiam o bem do universo. Ela é a energia líquida para o sonhador, a força vital do bem, o elemento bom da vida. Assim sendo, quando tocado pelo imaginário das águas claras, se imagina uma substância líquida, clara, fresca, limpa e revigorante. A água se torna fonte da juventude, uma substância pronta para curar os sonhos impuros, os devaneios pesados, os pesadelos passados. Ela é um instrumento de renovação, de rejuvenescimento. Uma matéria com o poder íntimo de purificação, capaz regenerar a alma do artista, segundo o autor (2013).

Pela teoria junguiana, essa representação simbólica da água pura assemelha-se ao arquétipo do inocente. Este definido por Ulson (1988) como a criança interior, cujas características são a criatividade, a futuridade, a sabedoria intuitiva, a renovação e o lúdico. Por essa perceptiva, entende-se que as águas claras retratam os traços de uma criança, principalmente pelo espírito alegre e aspecto puro diante das situações da vida. Além disso, a criança é símbolo de energia, de força e de vitalidade, traços semelhantes às águas claras descritas por Bachelard (2013). Dessa maneira, uma análise possível para as águas claras é que, em certas ocasiões oníricas, essas substâncias líquidas não apenas retratam a pureza dos rios e dos lagos, mas também a personalidade inocente e revigorante de uma criança. Em contrapartida, a água, em sua representação turva, configura outra simbologia e se distancia do arquétipo do inocente.

No jogo Magic: The Gathering, um dos elementos que potencializa a criação de novas imagens é a água, especialmente a água turva, também retratada como pântano. Neste jogo, o elemento aquático foi um bom condutor da imaginação e produziu uma série de imagens no imaginário dos seus criadores. Entretanto, diferente das águas claras, que simbolizam o arquétipo do inocente, as águas turvas ilustradas nas cartas de cor preta (nascidas

${ }^{4}$ No capítulo dedicado à água turva, veremos que a água pode multiplicar suas formas simbólicas. 
da energia - mana - do pântano), recorrem às imagens de ira, de luxúria, de soberba, de preguiça, de gula, de inveja e de avareza, considerados os sete pecados capitais no catolicismo e presente no imaginário de muitas pessoas, independente de religião. Assim, o pântano congrega seres infernais ligados aos pecados e distantes das imagens de água clara, materialização da pureza.

É perceptível nas imagens de ira a energia negativa irradiando contra os inimigos e sendo capaz de manipular e até destruí-los. Essa energia é um intenso e descontrolado sentimento de raiva, que sufoca sem nenhuma piedade os seus adversários, promovendo momentos de agonia e de desespero. Nas imagens de gula, tem-se a representação da fome e da sede nas criaturas do pântano. Uma compulsão voraz, quase impossível de controlar. Nas cartas, as criaturas do pântano aparentam querer sempre mais, não se contentando com poucas mortes, pois o desejo de matar parece não ter limites. A imagem da mordida simboliza o apetite voraz dessas criaturas. A avareza é materializada em seres que vivem no pântano (seus filhos). Seres apegados aos bens materiais, como o dinheiro, o ouro, a prata, o bronze, as joias. Essas imagens retratam a ganância excessiva e abusiva de ter alguma preciosidade ou poder. Nas imagens de luxúria, o prazer é exagerado, fica evidente o desejo insaciável, desequilibrado e egoísta por todo o prazer carnal e sexual que as criaturas dos pântanos emitem com seus corpos. Desse modo, a fisionomia charmosa e sedutora se transforma em uma arma letal, capaz de enlouquecer aqueles que cultuam a beleza corporal.

Ilustração 1 - Cartas de Ira, Gula, Avareza e Luxúria ${ }^{5}$

${ }^{5}$ Disponível em 26 mar. de 2017: http://magic.wizards.com/pt-br 

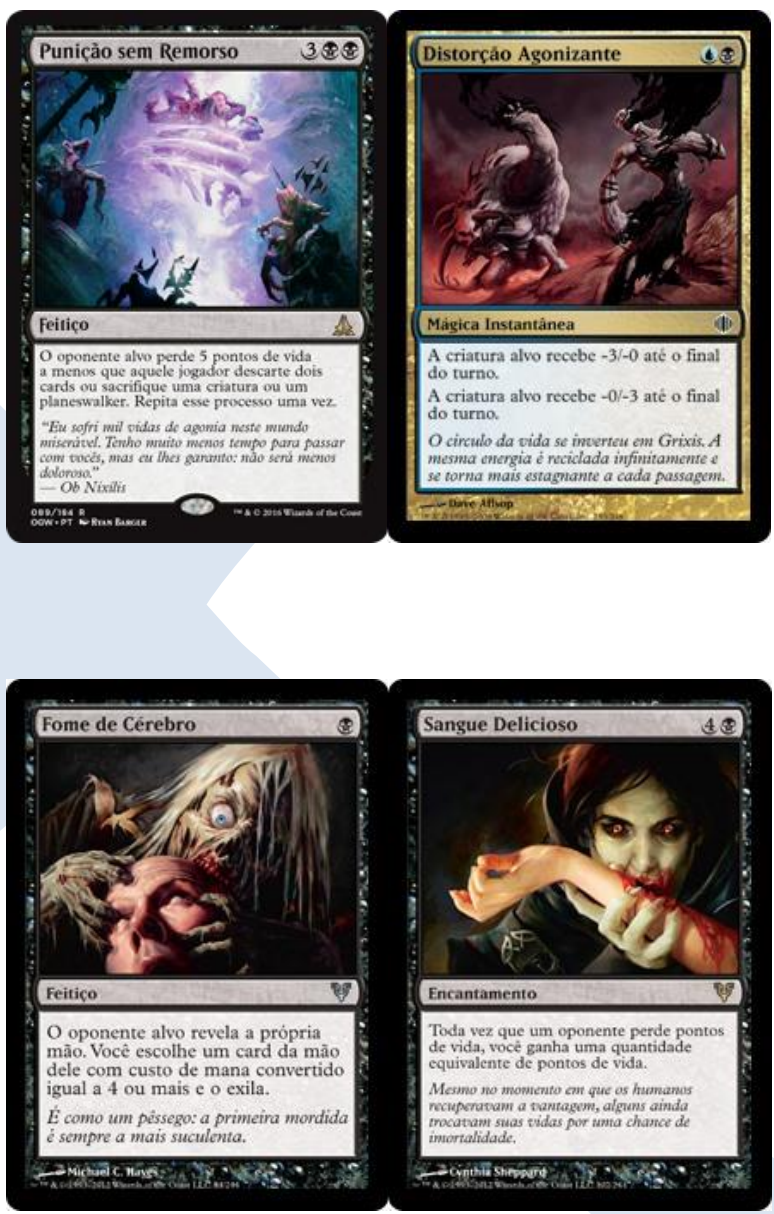

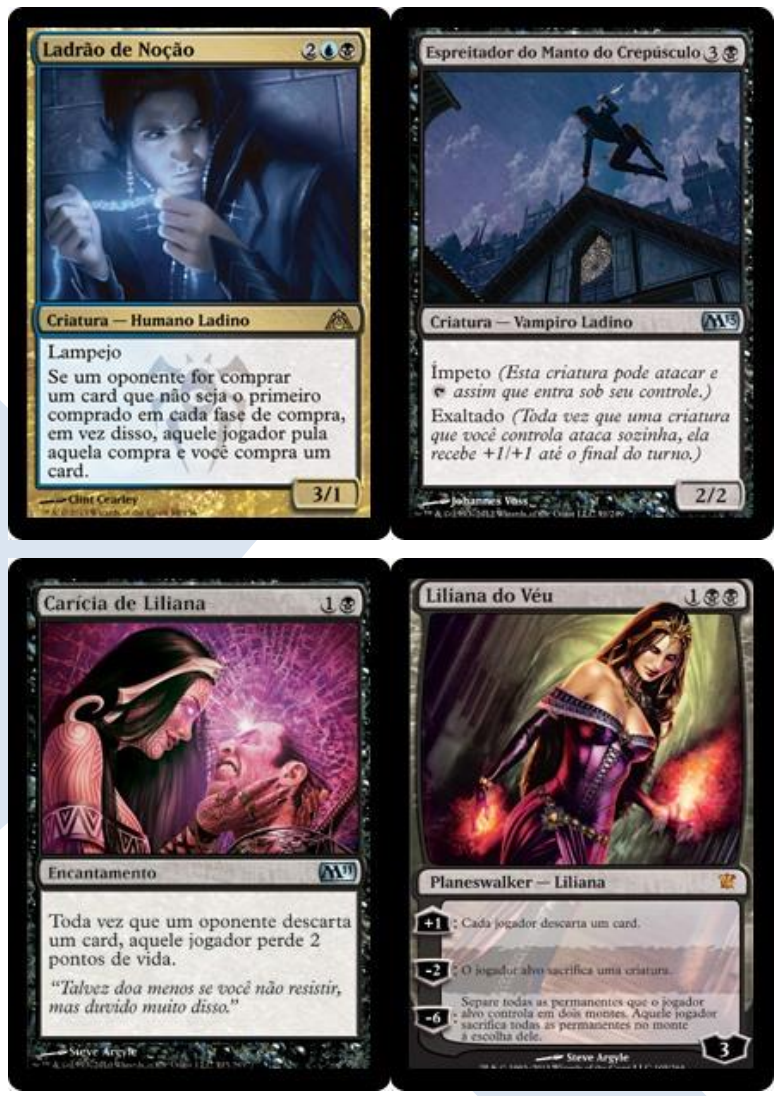

As imagens que denotam inveja retratam o ódio daqueles que servem o desejo do pântano contra seus adversários. As criaturas do pântano, enfurecidas com aqueles que estão em harmonia e aparentemente alegres, tentam de todas as formas gerar intrigas e afetá-los de modo malicioso e furtivo. A inveja, nessas figuras, é ilustrada pelo ataque por trás, um golpe certeiro e imprevisto. Nas ilustrações que indicam preguiça, há criaturas lentas, desleixadas, preguiçosas e quase sem forças para realizar suas tarefas. Em outras palavras, são seres sem esmero, empenho, moles, que não apresentam muita força de vontade em suas atividades. Isso porque, em muitas ilustrações, a preguiça é representada por mortos-vivos, monstros com poucas capacidades cognitivas e sem muita energia em seus corpos. Nas imagens de soberba, a vaidade ganha a cena e mostra o quanto os seres que 
vivem no pântano são excessivamente orgulhosos, presunçosos e arrogantes. Essas imagens caracterizam os servos do pântano como criaturas intimadoras e hostis, prontas para humilhar aqueles que obedecem ao desejo e ao poder da magia negra.

Ilustração 2 - Cartas de Inveja, Preguiça e Soberba ${ }^{6}$
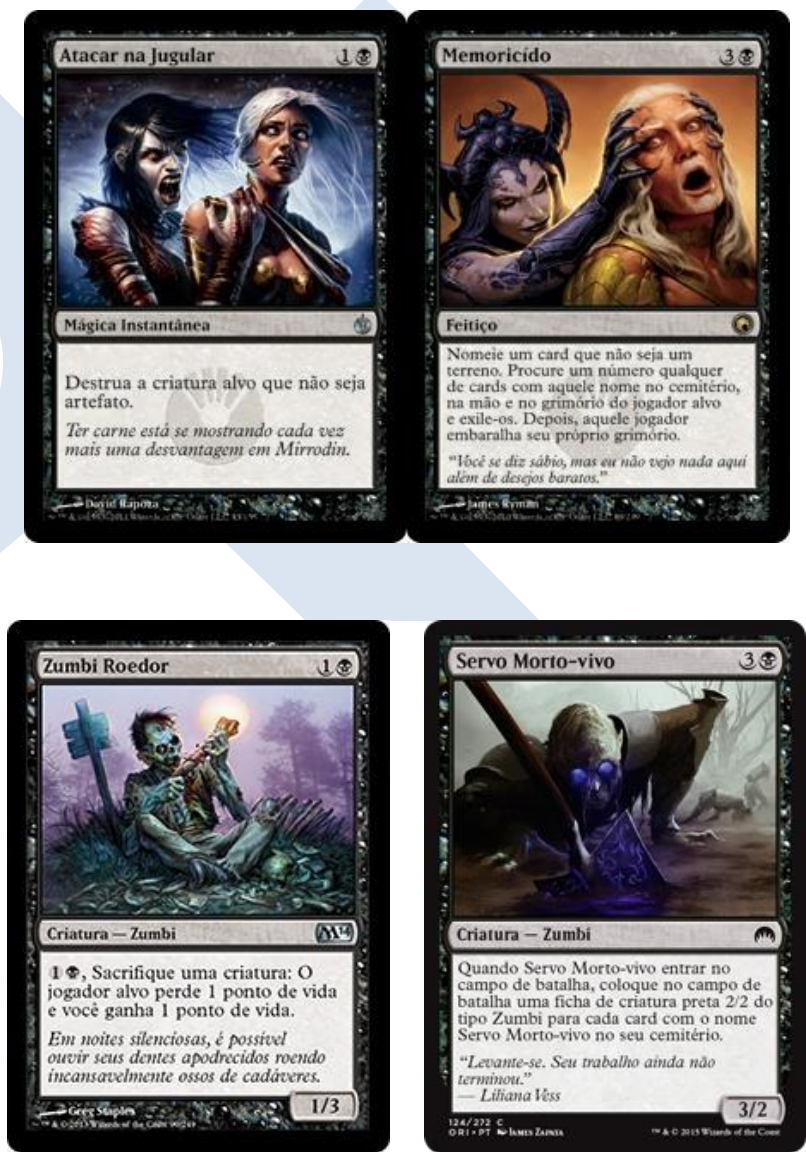

${ }^{6}$ Disponível em 26 mar. de 2017: http://magic.wizards.com/pt-br 

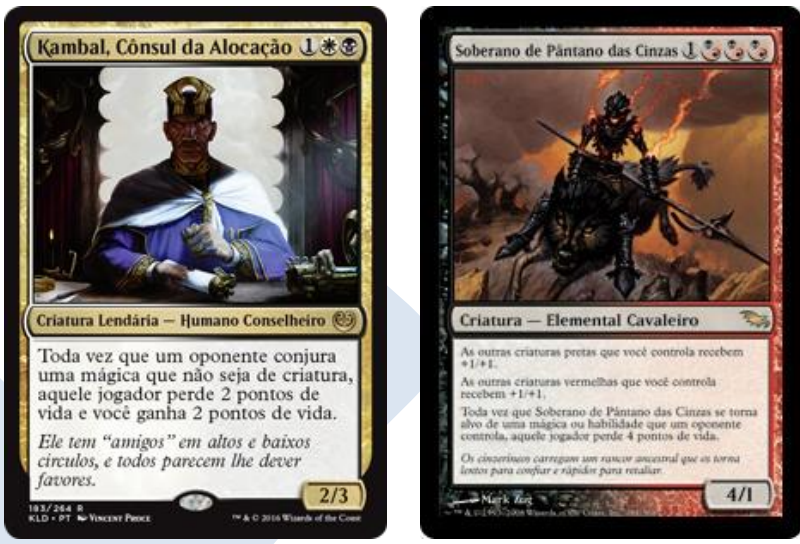

Nessas ilustrações, observa-se, assim, que há uma simulação daquilo que a Igreja Católica chama de pecado. Para Aguiar (2012), que estudou afundo os textos de Santo Agostinho e de São Tomás de Aquino, o pecado é qualquer ação, palavra ou medida contra a lei eterna, contra a lei de Deus. Visto que, nas ilustrações acima, não há qualquer tipo de imagem de bondade, de generosidade, de amor ou de demonstração de afeto divino, averígua-se, então, uma representação simbólica do pecado, uma manifestação do desejo do homem em seguir suas próprias vontades e não obedecer qualquer ordem divina.

Nessa direção, entende-se que as cartas de cor preta, compostas pelas mais nefastas e obscuras criaturas do jogo, nascidas da energia (mana) do pântano, são simbolicamente materializadas a partir das imagens dos sete pecados capitais. Reconhecidos socialmente, segundo aponta Aguiar (2012), como desvios de conduta, atitudes que no convívio social criam situações calamitosas, prejudiciais aos seres humanos entre si e em relação a si próprio.

A própria essência macabra e fúnebre da mana preta demonstra que a matriz arquetípica é a sombra. Na concepção de Von Franz (2002, p. 8-9), a sombra está interiorizada como parte da pessoa humana, é algo que o próprio indivíduo desconhece ou que não tem acesso diretamente, pois, se constitui a partir de "qualidades reprimidas, não aceitas ou não admitidas". A sombra é, para Von Franz (2002), o que está escondido no inconsciente, 
aquilo que é difícil acessar, o que, normalmente, fica repreendido, seja por ser um sentimento reprimido, seja por ser uma lembrança não aceita. Conforme o autor, a sombra é também conhecida por outros nomes, como o eu reprimido, o ego recalcado, o self inferior, o gêmeo (ou irmão) escuro das escrituras e dos mitos, o duplo, o eu rejeitado. Von Franz (2002) menciona que a sombra representa o lado escuro do ser humano, isto é, a face recalcada, que esconde, nas profundezes do inconsciente, os desejos mais terríveis, tristes e destrutivos do indivíduo. Ela age, na visão do teórico (2002), como uma defesa do sistema psíquico, definindo o que indivíduo pode ou não fazer, o que pode ou não falar, o que pode ou não manifestar. A sombra, em outros termos, é o exílio dos sentimentos e das emoções contidas, das tristezas e das raivas reprimidas.

De acordo com Jung (2008, p. 27), “[...] a natureza humana não é constituída apenas de pura luz, mas também de muita sombra”. A sombra é apontada por Jung (2008) como a parte mais obscura e negativa da personalidade. Ela está associada aos comportamentos, sentimentos e fantasias proibidas, às possibilidades negadas pela consciência. Ulson (1988:61) cita que a sombra presente nos sonhos aparece em forma "de pessoas com as quais não simpatizamos ou que tomamos como nossas inimigas". Ela é, na visão de Ulson (1988), uma unidade autônoma que reflete alguns aspectos negativos de cada indivíduo. Quando excessivamente negada, “a sombra é vista como um inimigo interno, o nosso lado sombrio, expressando nossos instintos sádicos e criminosos" (ULSON, 1998, p. 61). Em sua forma simbólica, Ulson (1998, p. 61) diz que a sombra é expressa pelos símbolos de maldade. No seu sentido amplo e coletivo, ela assume a forma do demônio, a sua configuração mais conhecida e maligna. Em complemento, Byington (1988) insinua que, apesar de a sombra se manifestar de modo inconsciente, ela não deixa de afetar a identidade do ser humano. Os símbolos expressados pela sombra promovem um sentimento de mal-estar e de incompletude à personalidade. De modo que o ser humano afetado por essas imagens e por essas emoções negativas se sente fragilizado, inferiorizado e debilitado: "quando esses 
símbolos são constantes, o que acontece sobremaneira no caso da sombra patológica, expressa, frequentemente por defesas estereotipadas, nos desmoralizamos perante os outros e nós mesmos" (BYINGTON, 1988, p. 64).

As imagens das cartas de cor preta, emergidas da energia do pântano, possuem o arquétipo da sombra como regente, uma vez que o imaginário do pântano é configurado por meio de imagens moralmente não aceitas, repelidas tanto pela sociedade quanto pela consciência do ser humano. Nas cartas se evidenciam imagens que retratam os sentimentos ocultos, muitas vezes não realizados, sobretudo por serem negligenciadas e repudiadas socialmente. De certo modo, esta análise corrobora com Baxter (1996), estudioso do jogo que afirma que as cartas pretas simbolizam o lado sombrio do ser humano, o lado oculto e intimidador de cada indivíduo, os desejos não efetuados, como, por exemplo, a vontade de matar, o interesse pela magia negra, a raiva contra os inimigos e o empenho pela vingança: "entre os espíritos negros da noite estão os magos que escolheram aliar-se com o maldito poder da morte. Esses magos trocaram a maior parte de sua humanidade pelo poder que emana dos brejos e pântanos, e que lhes dá um poder que poucos conseguem imaginar" (BAXTER, 1996, p. 41). Nos estudos bachelardianos, o pântano também ganha essa representação sombria. Para Bachelard (2013), quando a água, no imaginário do artista, escurece, fica turva, negra, fria, ela se torna um convite para a morte. As trevas, ao dominarem as águas, chama o poeta para se banhar e se afogar em um terrível e doloroso sonho.

Ao analisar Poe, cuja tristeza e dor se manifesta e se expressa na escrita, Bachelard (2013, p. 58) nota que "nele, cada hora meditada é como uma lágrima viva que vai unir-se à água dos lamentos; o tempo cai gota a gota dos relógios naturais; o mundo a que o tempo dá vida é uma melancolia que chora”. O autor afirma que o pântano, em sua força máxima, domina o coração e a alma do poeta. O espírito do artista se perde, fica aterrorizado pelas maldades da sombra, derrotado pelos desgostos e pelos remorsos da vida. A água escura, no imaginário do poeta, inunda suas palavras de amargura e de uma profunda tristeza. $\mathrm{O}$ pântano se transforma no elemento que retrata a morte e os mortos: "E quando chega o fim, quando as trevas estão no coração e na alma, quando os seres amados nos deixaram e 
todos os sóis da alegria desertaram a terra, então o rio de ébano, inchado de sombras, pesado de desgostos e de remorsos tenebrosos, vai começar sua lenta e surda vida" (BACHELARD, 2013, p. 59). Sobre o pântano, ou águas mortas, como prefere o autor (2013), é possível ainda mencionar que esse elemento é o suporte material da morte. O pântano, como propõe o filosofo, é a matéria que sugere a extinção, o fim de um ciclo. Quando as águas estão escuras, sujas, poluídas e impuras se imagina, imediatamente, o fim da vida. A água escura é um convite para um mergulho fatal, para o último banho. Em outros termos, o pântano é "a tinta da dor universal, a tinta das lágrimas” (BACHELARD, 2013, p. 37), a substância que conduz o homem à morte.

\section{Considerações finais}

Os pântanos, um dos elementos que induz o nascimento das criaturas do jogo, são retratados e configurados pela relação que tem com a imaginação dos seus criadores, como a substância dos desejos ocultos da natureza humana. Os pântanos ilustram os setes pecados capitais e simbolizam as imagens funestas que o arquétipo da sombra é capaz de produzir no imaginário de cada indivíduo. O pântano, por ser um elemento aquático, produz, na relação com o homem, a criação de imagens sombras, o que indica a ação transcendente da imaginação material bachelardiana (2013). É nesta relação com as águas que ficam turvas e maléficas - as mesmas águas que antes eram acolhedoras e puras, que transpiravam tranquilidade e paz - que o jogo Magic materializa a mana preta em imagens sombras.

Neste estudo, observou-se que as águas se transformam em pântanos e as criaturas que por lá transitam liberam seu lado mais maligno, seu lado tenebroso, a sua sombra. O pântano é, nesse caso, uma energia que contamina as almas e as transforma em escravos, serviçais sanguinários e sedentos de raiva. Nesse território, onde nada vive, onde tudo apodrece, até o espírito mais justo, até o ser mais puro, se revela um alvo fácil. A morte é quase certa. 
Conclui-se, a partir destas observações, que o arquétipo da sombra é o responsável pela produção da imaginação material que dá vida ao elemento pântano, e a mana preta é o próprio arquétipo materializado em energia que dá força maléfica aos magos do Multiuniverso. O jogo, que evoca uma narrativa, utiliza-se das cartas para guiar os jogadores. Nelas estão presentes as imagens, já reconhecíveis no imaginário social, que se colocam como potência poética na disputa entre os players.

\title{
TURKISH WATERS, A NARRATIVE SHADOW AND THE IMAGES OF SIN: THE MAGIC: THE GATHERING GAME
}

\begin{abstract}
:
This paper approximates the studies of the Theory of the Imaginary and Magic: The Gathering, a strategy card game that involves two or more players. For this purpose, we will do symbolic relation between the enchantments, spells, mythical creatures that nourish the game and the imaginary's concepts from Bachelard (2013) and Jung (2000). The analyzed excerpt figures in a particular gumption of the imaginary, which holds the power to control the strength of the swamps: the black mana. The analysis points out how the imaginary of the dark waters is configured, evoked and materialized on the construction of the narrative and the atmosphere that enlivens the game - identifying, through the Symbolic Hermeneutics, the Seven Deadly Sins as evokers of sense.
\end{abstract}

KEYWORDS: Image; Card game; Swamp; Turbid water; Sins.

\section{REFERÊNCIAS}

AGUIAR, J. A. S. Os sete pecados capitais: uma análise histórico-filosófica. 2 ed. Fortaleza: Gráfica LCR, 2012.

BAXTER, G. Dominando o Magic: The Gathering ${ }^{\text {TM; }}$ tradução Roque K. A.; São Paulo: Markon Books, 1996.

BACHELARD, G. Água e os sonhos: ensaio sobre a imaginação material, tradução Danise A. P. São Paulo: WMF Martins Fontes, 2013.

- A terra e os devaneios da vontade: ensaio sobre a imaginação das forças; tradução

Galvão M. E. A. P. 4 ed. São Paulo: WMF Martins Fontes, 2013. 
BYINGTON, C. Estrutura da personalidade: persona e sombra. São Paulo: Editora Ática, 1988.

DAGOGNET, F. Bachelard. Lisboa: Edições 70, 1980.

DURAND, G. Estruturas antropológicas do imaginário: introdução à arquetipologia geral. Tradução Godinho, H. 2. ed. São Paulo: Martins Fontes, 2001.

FERREIRA-SANTOS, M; ALMEIDA, R. Aproximações ao imaginário: bússola de investigação poética. São Paulo: Képos, 2012.

GOMES, E. S. L. A catástrofe e o imaginário dos sobreviventes: quando a imaginação molda o social. 2 ed. João Pessoa: Editora Universitária da UFPB, 2011.

JUNG, C. G. Os arquétipos e o inconsciente coletivo. Tradução Appy, M. L., Silva, D. M, R. F. Petrópolis: Vozes, 2000.

1988.

- Desenvolvimento da personalidade: símbolos e arquétipos. São Paulo: Editora Ática, . O eu e o inconsciente. Tradução Silva, D. M, R. F. 21 ed. Petrópolis: Vozes, 2008.

MORAES, H.J.P. Sob a perspectiva do imaginário: os mitos como categoria dos estudos da cultura e da mídia. In FLORES, Giovanna G. B. Flores; NECKEL, Nádia Régia Maffi; GALLO, Solange Maria Leda (orgs). Análise do Discurso em Rede: cultura e mídia. v.2. Campinas: Pontes, 2016.

PITTA, D. P.R. Iniciação à teoria do imaginário de Gilbert Durand. Recife: UFPE, 1995.

- Imaginário, cultura e comunicação. Revista eletrônica do Centro de Estudos do Imaginário. UFRO. Ano IV, n.6, jan-dez. 2004.

ULSON, C. O método junguiano. São Paulo: Ática, 1988.

VON FRANZ, M. A sombra e o mal nos contos de fada. Tradução Kujawski, M. C. P. São Paulo: Paulus, 1985.

Recebido em: 22/05/2018. Aprovado em: 16/07/2018. 